\title{
Development of Intentional Communicative Behavior in Korean Toddlers 12 to 30 Months
}

\author{
YoonKyoung Lee ${ }^{\mathrm{a}}$, HyoJoo Lee ${ }^{\mathrm{b}}$ \\ ${ }^{a}$ Division of Speech Pathology and Audiology, Hallym University, Chuncheon, Korea \\ ${ }^{b}$ Department of Speech-Language Pathology and Audiology, Graduate School of Hallym University, Chuncheon, Korea
}

Correspondence: YoonKyoung Lee, PhD Division of Speech Pathology and Audiology, Hallym University, 1 Hallymdaehak-gil, Chuncheon 24252, Korea

Tel: +82-33-248-2219

Fax: +82-33-256-3420

E-mail: ylee@hallym.ac.kr

Received: April 5, 2016

Revised: November 26, 2016

Accepted: November 29, 2016

This work was supported by Hallym University (HRF-201516-012).

\begin{abstract}
Objectives: The development of intentional communicative behaviors is closely related to later language development. This study aimed to examine the development of the intentional communicative behavior in Korean toddlers at 12 to 30 months. Methods: The participants were 41 typical developing Korean toddlers. The toddlers were classified by three age groups: 12-18 months, 19-24 months, and 25-30 months. A 10-minute behavior sample was obtained from each participant during interaction with their caregiver, from which the frequency of intentional communicative behaviors per minute, communicative functions (behavior regulatory, social interactional, and joint attentional functions), and means (gesture, vocalization, gesture with vocalization, verbal, verbal with gesture) of the behaviors were measured. Results: Results showed the following: intentional communicative behaviors per minute increased significantly with age. Analysis of communicative functions indicated that the rate of joint attentional and social interactional functions also significantly increased with age, however, in the number of sub-functions only increased in the joint attentional function. Analysis of communicative means showed that communicative gestures significantly decreased, but verbal communications with gestures and verbal means increased with age. The frequency of intentional communicative behaviors per minute, joint attentional functions, and verbal communications with gestures significantly predicted chronological age and language age. Conclusion: The results of this study help in understanding the development of intentional communicative behaviors in Korean toddlers during 12 to 30 months of age and have implications for assessing the communicative abilities in the toddler period and planning intervention for children with developmental language delay.
\end{abstract}

Keywords: Toddler, Intentional communicative behaviors, Communicative functions, Behavior regulation, Joint attention, Social interaction, Communicative means, Vocalization, Gesture, Verbal
의도적 의사소통행동(intentional communication behaviors)이 란 아동이 상대방에게 전달한 의도를 담은 행동을 말한다. 이는 아 동의 의도를 상대방이 파악하는 의사소통 효과는 가지나 그 의도 가 아동에 의해 분명하게 전달되었는지는 명확하지 않은 전의도적 인 의사소통행동(preintentional communication behaviors)과는 구분한다. 아기들은 언어를 산출하기 이전인 언어이전 시기부터 몸 짓이나 발성과 같은 비언어적 수단을 통해 자신의 의도를 다른 사 람에게 전달하는 방법을 배워나간다. 언어이전 시기의 의도적 의사
소통행동 발달은 이후 언어를 통한 의사소통 발달의 토대가 된다 (Brady, Marquis, Fleming, \& McLean, 2004; Calandrella \& Wilcox, 2000; Chiat \& Roy, 2008; Paul \& Roth, 2011; Watt, Wetherby, \& Shumway, 2006; Wetherby, Cain, Yonclas, \& Walker, 1988; Yoder, Warren, \& McCathren, 1998).

언어이전 시기부터 시작되는 의도적 의사소통 발달은 Bates, Camaioni와 Volterra (1975)의 이론에 의해 흔히 설명된다. 연구자들 은 3 명 아기에 대한 종단적 관찰을 통해 초기 의사소통 발달을 언 
YoonKyoung Lee, et al. • Development of Intentional Communicative Behavior in Toddlers 12 to 30 Months

향적(perlocutionary), 언표내적(illocutionary), 언표적(locutionary)의 세 단계로 설명하였다. 언향적 단계는 출생 후부터 약 9 개월 정도까지 해당하는데, 이때 아기들은 행동으로 인해 수반되는 결 과에만 관심을 보이며 다른 사람에게 의도를 전달하지 않는다. 이 시기의 아기는 아직 다른 사람에게 자신의 의도를 전달하지 않기 때문에 상대방이 아기의 행동을 통해 의도를 이해해야 한다. 다음 에 이어지는 언표내적 단계로 접어들면서 아기들은 자신의 행동이 다른 사람들에게 영향을 미칠 수 있음을 인식하고 자기 의도를 다 른 사람들에게 전달하기 시작한다. 그러나 아직 언어를 습득하지 못하였기 때문에 몸짓이나 발성과 같은 비언어적인 수단을 사용하 여 의도를 표현한다. 마지막 단계인 언표적 단계에서는 언어적 수단 을 사용하여 타인에게 의도를 전달하기 시작하는데, 보통 13 개월 전후에 시작된다. 언향적 단계에서 언표내적 단계로의 전환은 영유 아가 자신의 의도를 상대방에게 명확히 전달했는가를 중심으로 구분할 수 있으며, 언표내적 단계에서 언표적 단계로의 전환은 언어 적 수단을 사용했는가의 여부를 통해 구분할 수 있을 것이다.

Bates 등(1975)의 연구를 통해서도 알 수 있듯이, 영유아 시기의 의도적 의사소통행동의 발달은 상대방에게 의도가 명확히 전달되 었는가와 그리고 전달을 위해 사용한 수단을 중심으로 살펴볼 수 있다. 상대방에게 전달한 의도는 주로 의도적 의사소통행동의 빈 도와 의사소통기능을 중심으로, 그리고 사용 수단의 변화는 의사 소통수단을 중심으로 살펴볼 수 있다. 먼저 의사소통빈도는 언어 이전기에 출현하며, 연령 증가와함께 증가하는 경향을 보인다. Wetherby 등(1988)은 15 명의 영아들을 대상으로 언어이전단계(평균 12 개월), 한 낱말 단계(평균 16 개월), 낱말조합 단계(평균 24 개월) 시 기에 걸쳐 의도적 의사소통행동 발달을 종단적으로 살펴보았는데, 의도적 의사소통행동의 빈도가 언어이전 단계에서는 분당 1 회였으 나 한 낱말 단계에서는 분당 2 회, 낱말조합 단계에서는 분당 5 회 정 도로 증가하였다고 보고하였다. Chapman (2000)은 관련 선행연구 를 종합하여 의사소통 의도를 가진 발성이 $10-12$ 개월에는 10 분당 평균 25회 정도에서 13-18개월에는 50회로 약 두 배가 되며, 19-21 개월에는 75회로 수치에는 차이가 있으나 연령에 따른 증가 경향을 보고하였으며, Snow, Pan, Imbens-Bailey와 Herman (1996)도 14 개월에서 32 개월 영유아들의 종단적 연구를 통해 의도적 의사소통 행동이 10 분 동안 4 회에서 8 회 정도로 두 배 정도 증가하였다고 보 고하였다. 영유아의 의도적 의사소통행동의 빈도가 행동표본을 수 집한 조건에 따라 달라질 수 있기는 하나 대체로 12 개월 전후의 영 유아는 의도적 의사소통행동을 분당 1-2회 정도 산출하며, 18 개월 정도에는 2-5회 정도, 그리고 21-24개월 정도에는 5-7.5회 정도의 의 도적 의사소통행동 빈도를 보인다고 요약할 수 있다. 전형적 발달
을 보이는 영유아를 대상으로 한 앞의 연구들과는 다르게 발달장 애아동들을 대상으로 의도적 의사소통행동을 연구한 Yoder 등 (1998)은 비구어 단계에서 원시적 형태의 서술적 기능을 매 5 분 동 안 1 회 미만으로 사용하는 경우 기능적인 형태의 구어 발달에 어려 움이 있었다고 보고함으로써, 언어이전기 아동들도 자유놀이 상황 에서 최소한 5 분에 1 회의 의도적 의사소통행동을 보여야 함을 시 사하였다.

의도적 의사소통행동 빈도의 증가와 더불어 의도적 의사소통행 동이 어떤 기능으로 사용되었는지 역시 의사소통 발달의 주요 지 표가 된다. 의사소통기능이란 의도적 의사소통행동이 어떠한 목적 으로 사용되었는가를 나타내는 것으로, 영유아들은 연령이 증가 함에 따라 더욱 더 다양한 의사소통기능을 사용하게 된다. 영유아 시기에 관찰되는 의사소통기능은 여러 연구자들에 의해 다양하게 보고되었는데, 그 중 Dore (1975)는 언어이전 단계부터 언어출현기 영유아들에게서 관찰되는 의사소통기능을 명명하기, 반복하기, 대 답하기, 요구하기, 질문하기, 부르기, 인사하기, 항의하기, 연습하기 의 9가지로 제시하였으며, Halliday (1975)는 통제적, 상호작용적, 개인적, 표상적, 발견적, 상상적 기능의 6가지로 제시하였다(as cited in Owens, 2015). Chapman (2000)은 대체로 사물이나 행동 요구 또는 거부하기, 언급하기 등의 기능은 8-15개월경에 관찰되며, 질문 하기나 질문에 대답하기 등의 기능은 16-23개월경에 관찰된다고 보고하였다.

앞의 두 연구자들이 초기에 관찰되는 의사소통기능들을 나열하 여 제시한 반면, Bruner (1981)는 의사소통기능을 크게 행동통제 적, 사회적 상호작용적, 동시주의적 기능의 세 가지 범주로 유목화 하였다. 행동통제적 기능은 자기가 원하는 결과를 얻기 위해 다른 사람의 행동을 조절하는 것과 관련된 행동들로 주로 요구하기나 거부하기 행동이 포함되며, 사회적 상호작용적인 기능은 다른 사람 의 관심을 자신에게 유도하는 행동으로 부르기, 인사하기, 보여주 기 등이 포함된다. 동시주의적 기능은 다른 사람의 주의를 제 3 의 대상이나 사건으로 유도하는 기능으로 언급하기나 질문하기가 포 함된다. Wetherby 등(1988)의 연구에서는 Bruner (1981)의 분류체 계를 이용하여 언어이전, 한 낱말, 낱말조합 시기별로 사용된 의도 적 의사소통행동의 기능을 분석했는데, 세 단계 모두에서 세 가지 범주의 의사소통행동을 보였으나, 각 범주별 사용 비율에서는 유 의한 차이가 있었다고 보고하였다. 언어이전이나 한 낱말 단계에 비 해 낱말조합 단계에서는 더 여러 가지의 세부 의사소통기능을 보였 으며, 특히 사회적 상호작용 및 동시주의적 영역에서 더 다양한 유 형의 기능을 사용하였다고 보고하였다. Chapman (2000)과 Wetherby 등(1988)의 연구를 종합할 때, 12 개월경을 전후해서 행동통제 
적, 사회적 상호작용적, 동시주의적 기능이 모두 출현하나, 사용 빈 도 측면에서는 초기에는 행동통제적 기능이 주를 이루다 조금 뒤 늦게 사회적 상호작용적 기능과 동시주의적 기능의 빈도가 증가하 는 것으로 볼수 있다.

의도적 의사소통행동의 빈도나 의사소통기능과 더불어 의사소 통수단 역시 의사소통 발달의 지표가 된다. 의사소통수단에는 몸 짓, 발성, 얼굴표정 등과 같은 비언어적 수단과 언어적 기호체계를 통한 언어적 수단이 포함된다. 일반적으로 영유아들은 첫 낱말을 산출하기 전인 8-12개월 정도까지는 몸짓이나 발성과 같은 비언어 적 수단을 주된 의사소통수단으로 사용하다가 12-18개월에 언어 를 산출하기 시작하면서 점차 언어적 수단으로 이를 대체해 나간 다. 그러나 이 시기는 대부분의 아기들이 첫 낱말을 산출하기는 하 지만 의사소통 상황에서는 언어보다는 몸짓이나 발성과 결합된 형 태의 몸짓을 주된 의사소통 수단으로 사용한다. 낱말이나 낱말조 합과 같이 언어적 수단이 주된 의사소통수단으로 자리잡는 것은 18-24개월 정도가 되어야 가능해진다(Chapman, 2000; Jung \& Pae, 2006; Paul, 2007; Wetherby et al., 1988).

국내에서 영유아 시기의 의도적 의사소통행동과 관련된 연구는 대부분 언어발달지체(Cho \& Lee, 2010; Lim, Pae, \& Song, 2001)나 자폐범주성장애와 같은 발달장애 아동(Kim, Choi, \& Lee, 2015)의 의도적 의사소통을 영유아와 비교하거나, 혹은 사회적 의사소통행 동 중 일부로 살펴본 연구(Jeon, Lee, \& Lee, 2013; Lee \& Lee, 2013; Lee \& Lee, 2014)가 대부분이며, 일반 영유아를 대상으로 의도적 의 사소통 발달을 살펴 본 연구는 Hong과 Kim (2001)과 Kwak, Kim 과 Chang-Song (2004), 그리고 Kim (2004) 정도에 불과하다. Hong 과 $\operatorname{Kim}$ (2001)은 19 개월 영아 한 명을 24 개월까지 종단적으로 관찰 하여 의사소통 의도의 기능적 측면과 의도의 산출형태를 중심으 로 의도적 의사소통행동 발달을 살펴보았다. 연구 결과, 19 개월에 는 의사소통 의도가 반응과 요구가 전체의 절반 이상을 차지하였으 나 연령이 증가함에 따라 반응과 요구가 차지하는 비율은 감소하 는 반면 언급과 진술의 비율은 점차적으로 증가하였다. 또한 유형 의 종류도 연령 증가와 더불어 다양해져서 24 개월 경에는 연구자 들이 분석한 39 개 중 몇 개를 제외하고 거의 모두 나타냈다. 의사소 통 산출형태도 19 개월 경에는 몸짓과 발성을 결합한 형태가 $12 \%$ 정도 나타났으나 20 개월 이후에는 $4 \%$ 이하로 감소하여 대부분의 의사를 언어적 수단을 통해 표현한 것으로 보고하였다. Hong과 $\operatorname{Kim}$ (2001)의 연구는 초기 의도적 의사소통행동 발달을 종단적 연 구를 통해 보여주었다는 점에서 의의가 있으나 한 명의 영아만을 대상으로 보고된 자료이므로 결과를 일반화해서 이해하기에는 제 한이 있다. Kim (2004)은 의도적 의사소통행동의 빈도와 기능 발
달을 중심으로 $12-24$ 개월 영유아를 각각 $12,18,24$ 개월의 세 집단 으로 나누어 살펴보았다. CSBS-DP의 절차를 통해 수집된 행동표 본을 분석하였는데, 의도적 의사소통행동 빈도는 연령에 따라 점 차 증가하였으며, 12 개월에는 행동통제적 기능을, 24 개월에는 동시 주의적 기능이 유의하게 많이 사용되었다고 보고하였다. 그러나 이 연구는 CSBS-DP 절차를 통해 행동표본을 수집하였다고 제시하였 을 뿐 분석한 행동 표본의 길이에 대해 보고하지 않았다. 앞의 두 연 구가 의도적 의사소통행동의 빈도와 기능을 중심으로 연구한 반 면, Kwak 등(2004)은 8개월에서 18 개월 사이의 영유아들을 대상 으로 초기 비언어적 의사소통행동에서 보이는 의도성 발달에 대해 연구하였으나, 주로 가리키기 제스처를 중심으로 제스처 산출과 초기 의사소통능력 간의 관계를 살펴보는데 주된 목적을 두어 영 유아 시기의 의도적 의사소통 발달에 대한 포괄적인 결과를 제시 하지는 않았다.

서두에서도 제시하였듯이 언어이전기부터 시작되는 의도적 의 사소통행동 발달은 이후 의사소통 발달은 물론 언어 발달과도 밀 접한 관계를 갖는다. 따라서 영유아 시기의 의도적 의사소통행동 발달은 영유아의 이후 의사소통 및 언어 발달을 예측하게 해주므 로 전형적 발달을 이해하는 데에는 물론 언어 발달에 어려움을 갖 는 영유아를 조기에 발견하는데 도움을 줄 것이다. 또한 발달장애 아동들 중에는 영유아 시기 이후까지도 언어나 의사소통 발달이 초기 의사소통 발달 수준에 머물러 있는 경우가 많다. 따라서 초기 의도적 의사소통 발달에 대한 정보는 이와 같은 아동들을 평가하 고 중재하는데 의미 있게 활용될 수 있을 것이다.

이처럼 초기 의도적 의사소통 발달에 대한 이해는 학문적으로 나 임상적으로 중요하여 국외에서는 오래 전부터 연구되었으나 우 리나라의 경우는 초기 의도적 의사소통 발달에 대한 연구는 물론 자료가 매우 부족한 상황이다. 따라서 본 연구는 12 개월부터 30 개 월까지 영유아 시기의 초기 의도적 의사소통행동 발달을 의도적 의사소통행동 발달에서 중요한 변수로 고려하는 의도적 의사소통 행동 빈도, 의사소통기능, 의사소통수단의 세 가지 측면에서 살펴 보고자 하였다.

\section{연구 방법}

\section{연구 대상}

본 연구에는 $12-30$ 개월 사이의 영유아 41 명과 상호작용 대상자 로 주양육자 41 명이 참여하였다. 대부분의 자료는 제 1 연구자의 영 유아 의사소통 발달 종단적 연구 데이터베이스에 포함된 자료로, 모든 연구참여자들은 연구의 목적과 절차, 결과 활용에 대해서 사 
YoonKyoung Lee, et al. • Development of Intentional Communicative Behavior in Toddlers 12 to 30 Months COMmunication SCIINCES\& DIIORDERS

Table 1. Participants' characteristics

\begin{tabular}{lcccc}
\hline & \multicolumn{3}{c}{ Age group } & \\
\cline { 2 - 4 } & $\begin{array}{c}12-18 \mathrm{mo} \\
(\mathrm{N}=13)\end{array}$ & $\begin{array}{c}19-24 \mathrm{mo} \\
(\mathrm{N}=14)\end{array}$ & $\begin{array}{c}25-30 \mathrm{mo} \\
(\mathrm{N}=14)\end{array}$ \\
\hline $\begin{array}{l}\text { Chronological age (mo) } \\
\text { K-BSID-II }\end{array}$ & $15.23(2.52)$ & $22.50(1.40)$ & $28.00(1.57)$ & $156.616^{* * *}$ \\
$\quad$ Mental age (mo) & $16.92(2.87)$ & $24.14(1.83)$ & $30.57(3.88)$ & $70.581^{* * *}$ \\
Psycho-motor age (mo) & $17.08(3.38)$ & $23.79(2.39)$ & $30.50(1.99)$ & $87.858^{* * *}$ \\
SELSI & & & & \\
RLA (mo) & $17.54(3.93)$ & $23.93(7.27)$ & $28.36(2.24)$ & $16.106^{* * *}$ \\
ELA (mo) & $17.00(3.42)$ & $24.71(3.05)$ & $28.57(1.50)$ & $60.849^{* * *}$ \\
CLA (mo) & $17.15(3.89)$ & $25.71(2.97)$ & $28.64(1.60)$ & $54.865^{* * *}$ \\
\hline
\end{tabular}

Values are presented as mean (SD).

K-BSID-II= Korean Bayley Scales of Infant Development II (Cho, \& Park, 2006); SEL$\mathrm{SI}=$ Sequenced of Language Scale for Infants (Kim, Kim, Yoon, \& Kim, 2003); RLA= receptive language age; $E L A=$ expressive language age

${ }^{* * *} p<.001$.

전에 설명을 듣고 자발적으로 참여를 결정하였다.

영유아는 주양육자로부터 신경학적 손상을 포함한 전반적인 발 달에 문제가 없다고 보고된 영유아들 중에서 한국 베일리 영유아 발달검사II (K-BSID-II; Cho \& Park, 2006)와 영유아 언어발달검사 (SELSI; Kim, Kim, Yoon, \& Kim, 2003)를 실시하여 결과가 정상범 위에 속한 영유아로 하였다. K-BSID-II는 생활연령을 기준으로 운 동 및 인지 발달 지수가 정상 범위인 85-114 사이에 속하고 SELSI 결과도 '정상언어발달(+1 표준편차 이상)'에 해당하여 발달이 정상 적으로 이루어지는 영유아로 하였다. 또한 상호작용 대상자인 양육 자 요인을 통제하기 위하여 교육수준은 고졸 이상으로 제한하였다.

연구대상은 연령에 따른 발달을 살펴보기 위하여 영유아의 생활 연령에 기초하여 각 6개월을 간격으로 12-18개월, 19-24개월, 25-30 개월 세 집단으로 구분하였다. 12-18개월의 영유아 13명, 19-24개월 의 영유아 14 명, $25-30$ 개월 사이의 영유아 14 명이었다. 연구 참여자 정보는 Table 1 과 같다.

\section{연구 도구}

발달 검사 도구

연구 참여 영유아들의 전반적 발달은 한국 베일리 영유아 발달 검사II (K-BSID-II; Cho \& Park, 2006)를 이용하여 평가하였으며, 언어 발달 평가는 영유아 언어발달검사(SELSI; Kim et al., 2003)를 사용하여 실시하였다. K-BSID-II는 Bayley (1993)에 의해 개발된 검사를 한국판으로 표준화한 것을 사용하였다. K-BSID-II는 검사 자가 직접검사를 통해 영유아의 발달을 평가하도록 고안된 도구로 인지척도, 동작척도, 행동평정척도의 세 가지 척도로 구성되는데, 본 연구에서는 이 중 영유아의 인지, 언어, 개인-사회성, 대·소근육
운동 발달 수준을 평가하는 인지척도와 동작척도 결과만을 측정 하였다. SELSI는 양육자 보고를 통해 4-36개월 사이의 한국 영유아 의 언어 발달을 평가하도록 고안된 검사로 수용언어와 표현언어 발 달을 평가하도록 되어 있다. 본 연구에서는 수용, 표현 및 전체 언어 의 발달연령을 측정하였다.

\section{행동 표본 수집 도구}

영유아의 행동표본은 양육자와의 자유놀이 상황에서 수집하였 다. 행동표본 시 사용한 도구는 12-24개월 영유아를 대상으로 개발 된 의사소통 및 상징행동 척도(Communication and Symbolic Behavior Scale Developmental Profile, CSBS DP; Wetherby \& Prizant, 2002) 중 놀이 절차에서 사용되는 인형과 소꿉놀이 세트로, 본 연구의 대상 영유아의 연령에 적합하다고 판단되어 결정하였다.

\section{연구 절차}

자료수집에는 언어병리학전공 박사과정생 1 명과 자료수집 보조 자로 석사과정생 2 명이 참여하였다. 박사과정생은 한국판 베일리 영아발달검사(K-BSID-II)와 같은 영유아검사에 대해 훈련 받고 영 유아를 대상으로 자료수집 경험이 많은 사람으로, K-BSID-II의 실 시와 양육자에게 자료수집 목적 및 절차에 대해 설명하고 진행하 는 역할을 담당하였다. 석사과정생들은 자료수집을 보조하였으며, 주로 녹화를 담당하였다. 이들도 자료수집 전에 K-BSID-II와 연구 절차에 대해 교육과 훈련을 받은 후 자료수집에 참가하였다.

검사를 실시하기 전에 먼저 영아와 라포를 형성하기 위해 가정 내 익숙한 장난감을 사용하여 약 10 분 정도 놀이를 진행하였다. 영 유아가 검사자에게 어느 정도 익숙해졌다고 판단된 경우 K-BSID$\mathrm{II}$ 를 실시하였다. 영아가 검사 상황에 집중할 수 있도록 가정 내 조 용한 공간에서 유아용 테이블 및 의자를 사용하여 착석하도록 하 였고 스스로 착석하지 못하는 경우 양육자의 무릎에 앉힌 상태로 진행하였다. K-BSID-II 후 양육자와의 자유놀이 행동표본을 수집 하였다. 행동표본 수집에 앞서 먼저 양육자에게 영유아가 개시한 행동에 대해 반응해 주거나 확인해 주는 행동은 가능하나, 지시하 기나 질문하기와 같은 주도적인 행동은 최대한 자제하도록 하는 상 호작용 지침을 제공하였다. 모든 검사과정은 측정을 위해 사전 동 의를 얻어 디지털캠코더(Samsung DCR-SX83)로 녹화하였으며, 녹 화된 자료에서 도입부와마무리 및 정리 시간을 제외하고 영유아와 양육자 간의 상호작용이 발생한 10 분을 발췌하여 분석하였다.

\section{자료 분석 및 측정}

수집된 행동표본 중에서 놀이의 시작과 끝 부분을 제외하고, 상 
호작용이 활발하게 이루어진 10분만을 발췌하여 분석하였다(Cho \& Lee, 2010; Choi \& Lee, 2011; Kim \& Kwak, 2010; Kim, Lee, \& Lee, 2015; Kim \& Mahoney, 2004; Lee \& Lee, 2013, 2015; Lee \& Seol, 2010; Paul \& Shiffer, 1991; Rescorla \& Fechnay, 1996).

자료는 의도적 의사소통행동 빈도, 의사소통기능, 의사소통수단 의 세 가지 측면으로 분석하였다. 의도적 의사소통행동 빈도는 영 유아가 양육자에게 언어 또는 비언어적 수단으로 의도를 분명하게 전달한 경우만을 측정하였으며, 양육자의 지시나 질문에 대한 반 응이나 양육자에게 명확하게 전달되지 않은 행동은 제외하였다. 영유아가 보인 의도적 의사소통행동 전체 빈도를 10 으로 나누어 분당 의도적 의사소통행동 빈도로 측정하였다.

의사소통기능은 Bruner (1981)에 의해 제시되었으며, Wetherby 등(1988)이나 Wetherby와 Prizant (2002), Cho와 Lee (2010) 등 여 러 연구들에서 사용된 분류체계를 토대로 분석하였다. 이 분류체 계는 의도적 의사소통행동을 행동통제, 사회적 상호작용, 공동주 목의 세 범주로 구분하여 구분하여 유형별 사용 빈도와 각 의사소 통기능 범주별 하위 유형 수의 두 가지로 측정하였다. 세 범주의 의 사소통기능에 대한 조작적 정의는 Appendix 1에 제시하였다.

의사소통수단은 영유아들이 나타낸 의도적 의사소통행동을 몸 짓, 발성, 몸짓 동반 발성, 언어, 몸짓 동반 언어의 다섯 가지의 수단 으로 나누어 분석하여 의사소통기능과 마찬가지로 각각에 대한 사용 빈도를 측정하였다. 각 측정치에 대한 조작적 정의는 Wetherby 등(1988), Wetherby와 Prizant (2002), Cho와 Lee (2010)를 참 조하여 결정하였으며, 이는 Appendix 1에 제시하였다.

\section{신뢰도}

자료 분석에 대한 신뢰도는 연구자에 의해 측정된 결과와 신뢰 도 평가자 간의 일치도로 측정하였다. 신뢰도 평가자는 연구 보조 자로 참여한 석사과정생 중 1 인으로, 영유아의 의도적 의사소통행 동과 의사소통기능, 의사소통수단에 대한 훈련을 받았으며, 분석 경험이 많은 학생이었다. 먼저 신뢰도를 측정하기 전에 분석기준에 대해 검토하고 영유아 2 인의 자료를 통해 연습을 실시한 다음 이견 이 있는 부분에 대해 토론하는 과정을 거쳐 분석기준을 최대한 일 치되도록 하였다. 연습 후 전체 수집된 자료의 약 $15 \%$ 인 6명의 자료 를 임의로 선정하였으며, 독립적으로 분석하였다. 신뢰도 평가자 분석이 끝난 후 연구자가 분석한 자료와 일치한 부분과 불일치한 부분을 측정하고, 일치한 수를 일치와 불일치를 합한 수로 나눈 후 100 을 곱하여 일치도를 구하였다. 연구자와 신뢰도 평가자 간의 분 석 일치도는 분당 빈도 $99 \%$, 행동통제 $98.3 \%$, 사회적 상호작용 $99.5 \%$, 공동주목 $96.7 \%$, 몸짓 96\%, 발성 $98.8 \%$, 몸짓 동반 발성 97\%, 언어
$97 \%$, 몸짓 동반 언어 $98 \%$ 였다.

\section{통계 분석}

연령에 따른 의사소통행동의 분당 빈도는 일원분산분석(oneway ANOVA)으로, 연령에 따른 의사소통기능과 의사소통수단은 연령집단(3) $\times$ 의사소통기능(3), 연령집단(3) $\times$ 의사소통수단(5)의 반복측정 이원분산분석(repeated two-way ANOVA)을 실시하였 다. 의도적 의사소통행동 종속측정치들 중에 생활연령과 언어 발 달 수준과의 관계는 Pearson 상관분석과 단순회기 및 중다회기 분 석방법으로 분석하였다.

\section{연구 결과}

\section{연령에 따른 의도적 의사소통행동 빈도}

의도적 의사소통행동 빈도는 분당 의도적 의사소통행동의 빈도 로 측정하였다. 12-18개월, 19-24개월, 25-30개월 세 연령 집단의 분 당 의도적 의사소통행동 빈도를 비교한 결과는 Table 2 와 같다.

분당 의도적 의사소통행동의 빈도는 $12-18$ 개월에 $1.38,19-24$ 개 월에 2.22회, 25-30개월에 2.77회로 점차 증가하였다. 연령에 따른 의도적 의사소통행동 빈도에 대한 일원분산분석 결과, 집단 간 유 의한 차이를 보였다 $\left(F_{(2,38)}=18.537, p<.001\right)$. 사후분석 결과, $12-18$ 개월 집단은 19-24개월 집단과 25-30개월 집단에 비해 유의한차이 를 보였다.

\section{연령에 따른 의사소통기능 빈도 및 유형 수}

연령에 따른 의사소통기능의 발달은 행동통제적, 사회적 상호작 용적, 동시주의적 기능별로 나타난 행동 빈도와 각 범주별 세부 의 사소통기능의 유형 수, 두 차원에서 살펴보았다. 먼저 세 연령 집단 영유아들의 의도적 의사소통행동을 세 의사소통기능 범주로 구분 하여 반복측정 이원분산분석을 실시한 결과는 Table 3 과 같다.

반복측정 이원분산분석 결과, 연령 $(\mathrm{F}(2,38)=18.537, p<.001)$ 과 의사소통기능 $\left(F_{(2,38)}=23.201, p<.001\right)$ 의 주효과와 집단과 의사소 통기능 간의 상호작용 효과가 관찰되었다 $\left(F_{(2,38)}=4.158, p<.01\right)$. 연

Table 2. Frequency of intentional communicative behaviors according to age

\begin{tabular}{lccccc}
\hline & $12-18 \mathrm{mo}$ & $19-24 \mathrm{mo}$ & $25-30 \mathrm{mo}$ & $F$ & $p$-value \\
\hline $\begin{array}{l}\text { Communicative behav- } \\
\text { iors per minute }\end{array}$ & $1.38(.39)$ & $2.22(.55)$ & $2.77(.78)$ & $18.537^{* * *}$ & $.000^{\mathrm{a}, \mathrm{b}}$ \\
\end{tabular}

Values are presented as mean (SD).

${ }^{\mathrm{a}} 12-18 \mathrm{mo}$ vs. $19-24 \mathrm{mo},{ }^{\mathrm{b}} 12-18 \mathrm{mo} v \mathrm{ss} .25-30 \mathrm{mo}$.

${ }^{* * *} p<.001$. 
YoonKyoung Lee, et al. • Development of Intentional Communicative Behavior in Toddlers 12 to 30 Months COMmuniCATION SCIENCES\& DISORDERS

Table 3. Frequency of communicative behaviors according to age and category of communicative function

\begin{tabular}{|c|c|c|c|c|c|c|}
\hline & \multicolumn{4}{|c|}{ Main effect } & \multirow{2}{*}{\multicolumn{2}{|c|}{$\begin{array}{l}\text { Interaction effect } \\
\text { (age×category) }\end{array}$}} \\
\hline & \multicolumn{2}{|c|}{ Age } & \multicolumn{2}{|c|}{ Category } & & \\
\hline & $F_{(2,38)}$ & $p$-value & $F_{(2,38)}$ & $p$-value & $F_{(2,38)}$ & $p$-value \\
\hline Intentional communicative behavior & $18.537^{* * *}$ & $.000^{\mathrm{a}, \mathrm{b}}$ & $23.201^{* * *}$ & $.000^{c, d}$ & $4.158^{* *}$ & .004 \\
\hline
\end{tabular}

${ }^{\mathrm{a}} 12-18 \mathrm{mo}$ vs. $19-24 \mathrm{mo},{ }^{\text {b}} 12-18 \mathrm{mo}$ vs. 25-30 mo, "behavior regulation vs. social interaction, joint attention vs. social interaction.

${ }^{* *} p<.01,{ }^{* * *} p<.001$.

Table 4. Frequency of intentional communicative behaviors in each communicative function according to age

\begin{tabular}{|c|c|c|c|c|c|}
\hline \multirow{2}{*}{ Communicative function } & \multicolumn{3}{|c|}{ Age group } & \multirow{2}{*}{$F$} & \multirow{2}{*}{$p$-value } \\
\hline & $12-18 \mathrm{mo}$ & $19-24 \mathrm{mo}$ & 25-30 mo & & \\
\hline Behavior regulation & $8.54(3.13)$ & $10.43(4.64)$ & $9.43(5.91)$ & .540 & - \\
\hline Social interaction & $1.92(1.66)$ & $2.29(1.73)$ & 4.36 (3.34) & $4.150^{* *}$ & $.001^{\mathrm{b}}$ \\
\hline Joint attention & $3.31(1.97)$ & $9.50(5.00)$ & $13.93(7.93)$ & $12.218^{* * *}$ & $.000^{\mathrm{a}, \mathrm{b}}$ \\
\hline
\end{tabular}

Values are presented as mean (SD).

${ }^{\mathrm{a}} 12-18 \mathrm{mo}$ vs. 19-24 mo, ${ }^{\mathrm{b}} 12-18 \mathrm{mo} v \mathrm{ss} .25-30 \mathrm{mo}$.

${ }^{* *} p<.01,{ }^{* * *} p<.001$.

Table 5. Number of different communicative functions according to age and category of communicative function

\begin{tabular}{|c|c|c|c|c|c|c|}
\hline & \multicolumn{4}{|c|}{ Main effect } & \multirow{2}{*}{\multicolumn{2}{|c|}{$\begin{array}{l}\text { Interaction effect } \\
\text { (age ×category) }\end{array}$}} \\
\hline & \multicolumn{2}{|c|}{ Age } & \multicolumn{2}{|c|}{ Category } & & \\
\hline & $F_{(2,38)}$ & $p$-value & $F_{(2,38)}$ & $p$-value & $F_{(2,38)}$ & $p$-value \\
\hline Number of different communicative functions & $3.923^{*}$ & $.028^{\mathrm{a}}$ & $19.806^{* * *}$ & $.000^{\mathrm{b}, \mathrm{c}}$ & $2.496^{*}$ & .028 \\
\hline
\end{tabular}

${ }^{\mathrm{a}} 12-18 \mathrm{mo}$ vs. 25-30 mo, bbehavior regulation vs. social interaction, cjoint attention vs. social interaction. ${ }^{*} p<.05,{ }^{* * *} p<.001$.

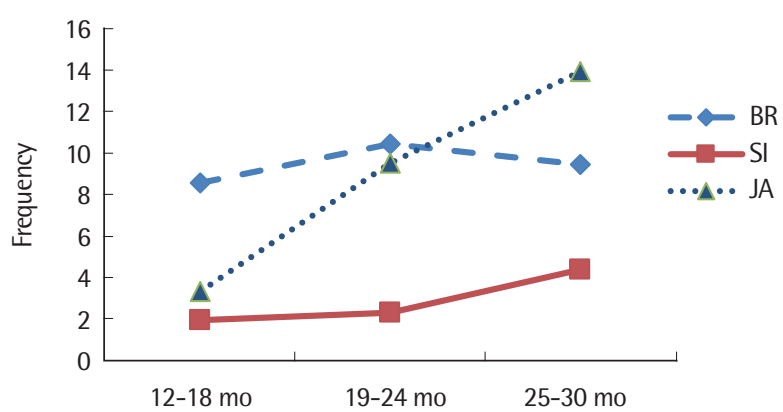

Figure 1. Frequency of three communicative functions: behavior regulation (BR), social interaction (SI), and joint attention (JA).

령과 의사소통기능 간의 상호작용 효과를 살펴보기 위해 일원분산 분석을 실시한 결과는 Table 4, Figure 1과 같다.

의사소통기능 범주 중 행동통제적 기능 범주에서는 연령 집단 간에 유의한 차이가 없었던 반면, 사회적 상호작용 $\left(F_{(2,38)}=4.150\right.$, $p<.01)$ 과 동시주의 $\left(F_{(2,38)}=12.218, p<.001\right)$ 기능 범주에서는 연령 집단 간에 유의한 차이를 보였다. Tukey 사후분석 결과, 사회적 상 호작용은 12-18개월과 25-30개월 간에 유의한 차이가 있었으며, 동
시주의는 12-18개월과 19-24개월이 25-30개월과 각각 유의한 차이 가 있었다. 행동통제적 기능의 경우 연령 증가에 따라 빈도에 유의 한 변화가 없었던 반면, 사회적 상호작용적 기능은 25-30개월에 유 의하게 행동 빈도가 증가하였고, 동시주의적 기능도 연령 증가에 따라 점진적으로 유의하게 증가하였다.

또한 12-18개월에는 행동통제적인 기능이 사회적 상호작용 $(t=$ $7.636, p<.001)$ 과 동시주의 $(t=4.527, p<.01)$ 에 비해 유의하게 많이 사용된 반면, 19-24개월에는 사회적 상호작용에 비해 행동통제적 $(t=5.550, p<.001)$ 기능과 동시주의 $(t=-6.498, p<.001)$ 기능이 유 의하게 높은 빈도로 사용되었다. 25-30개월에도 사회적 상호작용에 비해 행동통제적 $(t=2.702, p<.05)$ 및 동시주의 $(t=-3.757, p<.01)$ 기능이 유의하게 많이 사용되었으며 19-24개월에 비해 동시주의 기능이 월등하게 높은 빈도로 사용되었다. 이처럼 연령과 의사소통 기능 간의 상호작용 효과는 의사소통기능 범주별 빈도가 연령 집 단에 따라 다른 양상으로 나타난 것으로 설명할 수 있다.

세 연령 집단의 영유아들이 세 의사소통기능 범주별로 나타낸 하위 의사소통기능의 유형 수에 대해 연령과 의사소통기능 범주를 독립변수로 하여 반복측정 이원분산분석을 실시한 결과는 Table 5 
와 같다.

반복측정 이원분산분석 결과, 의사소통기능 범주별 하위 의사 소통기능 유형 수에서 연령 $\left(F_{(2,38)}=3.923, p<.05\right)$ 과 의사소통기능 범주 $\left(F_{(2,38)}=19.806, p<.001\right)$ 의 주효과와 집단과 의사소통기능 범 주 간의 상호작용 효과가 관찰되었다 $\left(F_{(2,38)}=2.496, p<.05\right)$. 연령과 의사소통기능 간의 상호작용 효과를 살펴보기 위해 일원분산분석 을 실시한 결과는 Table 6, Figure 2와같다.

의사소통기능 범주 중 행동통제적 기능 범주와 사회적 상호작용 기능 범주에서는 하위 의사소통기능 유형 수에서 연령 집단 간에 유의한 차이가 없었던 반면, 동시주의 $\left(F_{(2,38)}=16.277, p<.001\right)$ 기능 범주에서는 연령 집단 간에 유의한 차이를 보였다. Tukey 사후분 석 결과, $12-18$ 개월과 25-30개월 간에 유의한 차이가 있었다. 즉, 행 동통제적 기능 범주의 하위 유형수는 12-18개월부터 25-30개월까 지 큰 변화가 없었던 반면 사회적 상호작용과 동시주의적 기능의

Table 6. Number of different communicative functions according to age

\begin{tabular}{|c|c|c|c|c|c|}
\hline \multirow{2}{*}{$\begin{array}{l}\text { Communicative } \\
\text { function }\end{array}$} & \multicolumn{3}{|c|}{ Age group } & & \multirow{2}{*}{$p$-value } \\
\hline & $12-18 \mathrm{mo}$ & 19-24 mo & 25-30 mo & & \\
\hline Behavior regulation & 2.31 (.63) & $2.29(.47)$ & $2.21(.80)$ & .078 & .925 \\
\hline Social interaction & $1.00(.82)$ & 1.07 (.83) & $1.43(.65)$ & 1.230 & .304 \\
\hline Joint attention & $1.00(.00)$ & $1.14(.36)$ & $1.71(.47)$ & $16.277^{* * *}$ & $.000^{\mathrm{a}}$ \\
\hline
\end{tabular}

Values are presented as mean (SD).

a12-18 mo vs. 25-30 mo.

${ }^{* * *} p<.001$.

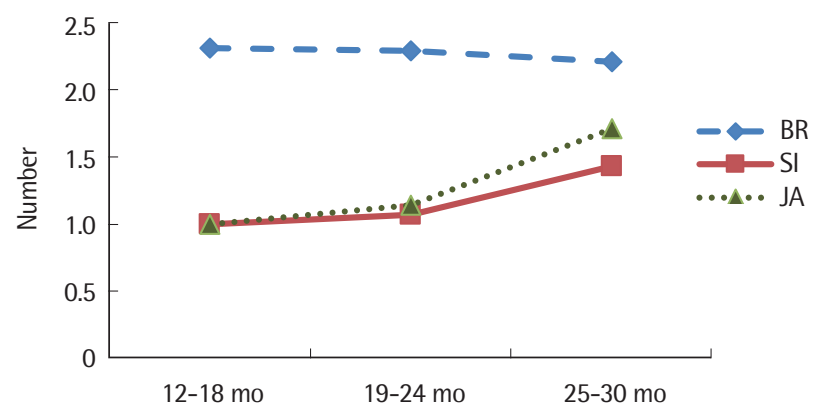

Figure 2. Number of different communicative functions: behavior regulation (BR), social interaction (SI), and joint attention (JA).
하위 유형수는 12-18개월에서 19-24개월까지는 큰 변화가 없다가 25-30개월에 이르면 유형수가 증가하는 경향을 보였다.

또한 12-18개월에는 행동통제적인 기능의 하위 유형이 사회적 상호작용 $(t=4.977, p<.001)$ 과 동시주의 $(t=7.479, p<.001)$ 기능의 하위 유형수가 유의하게 많았으며, 19-24개월에도 행동통제적인 기능의 하위 유형수가 사회적 상호작용 $(t=5.090, p<.001)$ 과 동시 주의 $(t=8.000, p<.001)$ 기능에 비해 유의하게 많았다. 반면, 25-30 개월에는 행동통제적 기능이 사회적 상호작용 기능에 비해 유의하 게 다양한 하위 유형을 보였으며 $(t=2.702, p<.05)$ 다른 기능 간에 는 하위 유형 수에 유의한 차이가 없었다.

\section{의사소통기능 수단에 따른 의도적 의사소통행동 빈도}

세 연령 집단의 영유아들의 의도적 의사소통행동을 몸짓, 발성, 몸짓 동반 발성, 언어, 몸짓 동반 언어의 다섯 가지로 나누어 반복측 정 이원분산분석을 실시한 결과는 Table 7과같다.

반복측정 이원분산분석 결과, 연령 $\left(F_{(2,38)}=30.671, p<.001\right)$ 과 의 사소통수단 $\left(F_{(2,38)}=18.717, p<.001\right)$ 의 주효과와 연령과 의사소통 수단 간 상호작용 효과가 관찰되었다 $\left(F_{(2,38)}=17.227, p<.001\right)$. 연령 과 의사소통수단 간의 상호작용 효과를 살펴보기 위해 일원분산 분석을 실시하였으며, 그 결과를 Table 8과 Figure 3에 제시하였다.

의사소통수단 중 몸짓 $\left(F_{(2,38)}=14.846, p<.001\right)$, 구어 $\left(F_{(2,38)}=17.967\right.$, $p<.001)$, 몸짓 동반 언어 $\left(F_{(2,38)}=23.793, p<.001\right)$ 연령 집단 간에 유의한 차이를 보였으며, 발성과 몸짓 동반 발성에서는 유의한 차 이가 없었다. Tukey 사후분석 결과, 몸짓과 몸짓 동반 언어는 12-18

Table 8. Comparison of intentional communicative means

\begin{tabular}{|c|c|c|c|c|c|}
\hline & \multicolumn{3}{|c|}{ Age group } & \multirow{2}{*}{ 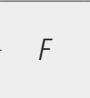 } & \multirow{2}{*}{$p$-value } \\
\hline & $12-18 \mathrm{mo}$ & 19-24 mo & $25-30 \mathrm{mo}$ & & \\
\hline Gesture & $8.77(3.37)$ & $3.29(2.58)$ & $4.00(2.48)$ & 14.846 & $.000^{a, b}$ \\
\hline Vocalization & $.69(.85)$ & $.79(.97)$ & $.29(.61)$ & 1.439 & - \\
\hline Gesture+vocalization & $2.31(2.81)$ & 2.64 (2.68) & $.86(1.29)$ & 2.273 & - \\
\hline Verbal & $.85(1.46)$ & $6.29(4.89)$ & $11.07(5.61)$ & 17.967 & $.000^{a, b, c}$ \\
\hline Gesture+verbal & $1.15(1.72)$ & $9.14(3.57)$ & $11.50(5.72)$ & 23.793 & $.000^{a, b}$ \\
\hline
\end{tabular}

Values are presented as mean (SD).

a $12-18$ mo vs. $19-24 \mathrm{mo},{ }^{\mathrm{b}} 12-18 \mathrm{mo}$ vs. 25-30 mo, ${ }^{\circ} 19-24 \mathrm{mo} v \mathrm{ss} .25-30 \mathrm{mo}$.

Table 7. Intentional communicative behaviors according to age and communicative functions

\begin{tabular}{|c|c|c|c|c|c|c|}
\hline & \multicolumn{4}{|c|}{ Main effect } & \multirow{2}{*}{\multicolumn{2}{|c|}{$\begin{array}{l}\text { Interaction effect } \\
\text { (age ×category) }\end{array}$}} \\
\hline & \multicolumn{2}{|c|}{ Age } & \multicolumn{2}{|c|}{ Category } & & \\
\hline & $F_{(2,38)}$ & $p$-value & $F_{(2,38)}$ & $p$-value & $F_{(2,38)}$ & $p$-value \\
\hline Intentional communicative behaviors & $18.717^{* * *}$ & $.000^{\mathrm{a}}$ & $30.671^{* * *}$ & .000 & $17.227^{* * *}$ & .000 \\
\hline
\end{tabular}

${ }^{a} 12-18 \mathrm{mo}$ vs. 19-24 mo.

${ }^{* * *} p<.001$. 
YoonKyoung Lee, et al. • Development of Intentional Communicative Behavior in Toddlers 12 to 30 Months COMmuniCATION SCIENCES\& Disorders

Table 9. Correlation between chronological age, language age, communicative functions, and communicative means

\begin{tabular}{|c|c|c|c|c|c|c|c|c|c|c|c|c|}
\hline & $\mathrm{CA}$ & RLA & ELA & CLA & Frequency/min & $\mathrm{BR}$ & $\mathrm{SI}$ & $\mathrm{JA}$ & Ges & vocal & Ges+ vocal & verbal \\
\hline Frequency/min & $.647^{* * *}$ & $.431^{* *}$ & $.637^{* * *}$ & $.610^{* * *}$ & & & & & & & & \\
\hline BR & -.004 & .007 & -.061 & -.084 & $.355^{*}$ & & & & & & & \\
\hline $\mathrm{Sl}$ & $.408^{* *}$ & .219 & $.349^{*}$ & $.325^{*}$ & $.417^{* *}$ & -.080 & & & & & & \\
\hline JA & $.611^{* * *}$ & $.420^{* *}$ & $.659^{* * *}$ & $.651^{* * *}$ & $.781^{* * *}$ & -.223 & .174 & & & & & \\
\hline Ges & $-.590^{* * *}$ & $-.466^{* *}$ & $-.647^{* * *}$ & $-.657^{* * *}$ & $-.422^{* *}$ & .141 & -.161 & $-.529 * * *$ & & & & \\
\hline vocal & -.219 & -.141 & -.260 & -.259 & -.091 & $.526^{* * *}$ & -.129 & $-.412^{* *}$ & .094 & & & \\
\hline Ges+vocal & -.209 & -.045 & -.200 & -.188 & .041 & $.345^{*}$ & -.014 & -.178 & -.079 & $.343^{*}$ & & \\
\hline verbal & $.650^{* * *}$ & $.388^{*}$ & $.672^{* * *}$ & $.633^{* * *}$ & $.801^{* * *}$ & -.106 & $.381^{*}$ & $.869^{* * *}$ & $-.547^{* * *}$ & $-.351^{*}$ & -.241 & \\
\hline Ges+verbal & $.715^{* * *}$ & $.527^{* * *}$ & $.714^{* * *}$ & $.719^{* * *}$ & $.819^{* * *}$ & $.295^{* *}$ & $.311^{*}$ & $.648^{* * *}$ & $-.621^{* * *}$ & -.105 & -.114 & $.569^{* * *}$ \\
\hline
\end{tabular}

$\mathrm{CA}=$ chronological age; $\mathrm{RLA}=$ receptive language age; $\mathrm{ELA}=$ expressive language age; $\mathrm{CLA}=$ combined language age; $\mathrm{BR}=$ behavior regulation; $\mathrm{SI}=$ social interaction; $\mathrm{JA}=$ joint attention; Ges = gesture; Vocal = vocalization .

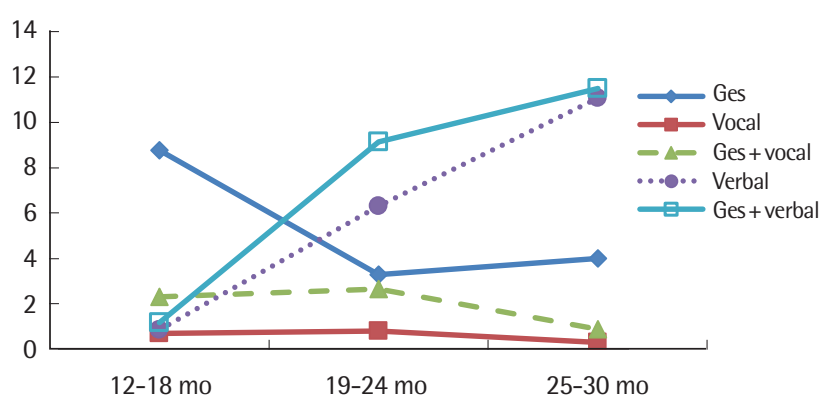

Figure 3. Intentional communicative behaviors according to age and communicative means. Ges= gesture; vocal = vocalization .

개월 집단이 19-24개월, 25-30개월과 각각 유의한 차이를 보였으며, 언어는 12-18개월이 19-24개월, 25-30개월과, 그리고 19-24개월이 25-30개월과 유의한 차이를 보였다.

또한 12-18개월에는 몸짓을 다른 의사소통수단에 비해 유의하 게 높은 빈도로 사용하였으며, 19-24개월에는 몸짓 동반 언어를 주 된 수단으로 사용하면서 몸짓 동반 언어와 더불어 언어를 발성이 나 몸짓, 몸짓 동반 발성에 비해 유의하게 높은 빈도로 사용하였다. 25-30개월에는 언어와 몸짓 동반 언어를 다른 수단에 비해 유의하 게 많이 사용하였을 뿐 아니라 발성 및 몸짓 동반 발성은 유의하게 적은 빈도로 사용하였다. 연령과 의사소통수단 간의 상호작용 효 과는 연령에 따라 주되게 사용하는 수단의 변화로 인한 것으로 해 석된다.

\section{생활연령 및 언어 발달과 의사소통기능 및 수단 간의 관계}

영유아의 의도적 의사소통행동이 연령 및 언어 발달에 미치는 영향을 살펴보기 위하여 의도적 의사소통행동 변수들, 즉 분당 의 도적 의사소통행동 빈도, 세 의사소통기능 범주, 다섯 가지 의사소 통수단과 생활연령 및 언어연령 간의 Pearson 상관분석과 단순회 귀분석을 실시하였다. 상관분석 결과는 Table 9와 같다.
Pearson 상관분석 결과, 생활연령과는 분당 의도적 의사소통행 동 빈도, 의사소통기능 중 동시주의적 기능과 사회적 상호작용 기 능과 정적 상관이 있었으며, 의사소통수단 중에는 언어와 몸짓 동 반 언어가 유의한 정적 상관이, 몸짓은 부적 상관이 있었다. 언어연 령도 생활연령과 마찬가지로 분당 의도적 의사소통행동 빈도, 의 사소통기능 중 동시주의적 기능과 사회적 상호작용 기능과 정적 상 관이 있었으며, 의사소통수단 중에는 언어와 몸짓 동반 언어가 유 의한 정적 상관이, 몸짓은 부적 상관이 있었다. 전반적으로 수용언 어연령에 비해 표현언어연령이 높은 상관을 보였다.

의사소통기능과 수단 변수들 간의 관계를 보면, 행동통제적인 기능은 발성, 몸짓 동반 발성, 몸짓 동반 언어와 유의한 정적 상관을 보였으며, 사회적 상호작용 및 동시주의적 기능은 언어, 몸짓 동반 언어와 유의한 상관을 보였다. 의사소통기능 범주 간에는 유의한 상관이 없었으나, 의사소통수단 간에는 언어와 몸짓, 언어와 발성 간에 유의한 부적 상관이 있었다.

단순중다회귀분석을 통해 분석한 결과, 분당 의도적 의사소통 행동 빈도는 생활연령을 $41.9 \%$ ( $p<.001)$, 표현언어연령을 $40.6 \%$ $(p<.001)$ 유의하게 설명하였다. 또한 단계적 중다회귀분석을 통해 서 분석한 결과, 의사소통행동 기능 중에서는 동시주의 기능이 생 활연령을 $37.3 \%$ ( $p<.001)$, 표현언어연령을 $43.6 \%$ ( $p<.001)$, 사회적 상호작용 기능이 생활연령과 표현언어연령을 각각 $9.6 \%(p<.05)$ 와 $5.6 \%(p<.05)$ 설명하였다. 의사소통수단에서는 몸짓 동반 언어가 생활연령을 $51.1 \%$ ( $p<.001)$, 표현언어연령을 $51 \%$ ( $p<.001$ ) 설명하 였으며, 언어가 생활연령을 $8.8 \%$ ( $p<.01)$, 표현언어연령을 $10.5 \%$ $(p<.01)$ 설명하였다.

\section{논의 및 결론}

본 연구는 12 개월에서 30 개월 사이의 영유아들의 의도적 의사 
소통행동 발달을 양육자와의 놀이 상호작용 상황에서 수집한 행 동표본을 통해 살펴보았다. 의도적 의사소통행동은 분당 나타난 의도적 의사소통 행동의 빈도, 의사소통기능, 의사소통수단의 세 가지 측면을 통해 연구하였다. 다음에서는 각각의 측정치 별로 연 구를 통해 나타난 결과에 대해 고찰해 보고자 한다.

먼저, 분당 의도적 의사소통행동의 빈도는 12-18개월에 1.38 회, $19-24$ 개월에 2.22회, 25-30개월에 2.77회로 점차 증가하였다. 영유 아 시기에 연령이 증가함에 따라 의도적 의사소통행동이 증가한다 는 사실은 12 개월에서 24 개월 혹은 30 개월 정도의 어린 아기들을 대상으로 한 여러 연구들에서 보고되었다(Chapman, 2000; Snow et al., 1996; Wetherby et al., 1988). 본 연구에서도 선행연구와 마찬 가지로 의도적 의사소통행동의 빈도가 유의하게 증가하여 의도적 의사소통행동 빈도가 초기 의사소통 발달 정도를 보여주는 중요한 지표가 될 수 있음을 보여주었다. 분당 산출빈도는 12-18개월에 1.38 회로 분당 1-2회 정도를 보고한 선행연구들과 큰 차이가 없었다. 그 러나 19-24개월에는 2.22회, 25-30개월에는 2.77회로 각각 2-5회, 5-7회로 증가하였다고 보고한 선행연구에 비해서는 증가폭이 적었 다. 이는 다음과 같은 두 가지 측면에서 고려해 볼 수 있다. 첫째는 행동표본을 수집한 조건에서의 차이이다. 선행연구 중 영유아의 행 동을 직접 분석한 Wetherby 등(1988)은 자유놀이와 구조화된 유 도절차에서 동일하게 얻어진 행동표본을 분석한 반면, 본 연구는 자유놀이 상황에서 수집된 자료만을 분석하였다. 일반적으로 구 조화된 상황에서는 의도적 의사소통행동 빈도가 더 증가할 수 있 으므로 이러한 차이가 행동빈도에 반영되었을 수 있다. 둘째는 우 리나라 영유아들이 상대적으로 의도적 의사소통행동 빈도를 적게 나타낼 수 있다는 점이다. 미국과 프랑스, 일본 영유아와 양육자 간 의 상호작용행동을 비교한 연구에서 영유아와 양육자 간의 상호작 용 스타일이 문화적으로 차이가 있으며, 일본 아기와 양육자들이 미국이나 프랑스 아기와 양육자에 비해 상호작용이 정적이고 소극 적인 경향을 보였다고 보고된 바 있다(Bornstein et al., 1992). 상호 작용 방식은 영유아 시기의 의사소통행동과 밀접한 관계를 가지므 로 초기 의도적 의사소통행동 빈도는 이와 관계될 수 있다. 국내에 서 이루어진 Kim (2004)의 연구는 CSBS-DP 절차를 통해 영유아 의 의도적 의사소통행동 빈도를 측정하였는데 분당 의도적 행동이 12 개월에는 1.2 회, 18 개월에는 2.8 회, 24 개월에는 3.9 회 정도였다고 보고하여 Wetherby 등(1988)에 비해서는 적은 빈도를, 본 연구에 비해서는 약간 높은 빈도를 보고하였다. 이러한 결과는 행동표본 유도절차와 문화적 요소가 고르게 영향을 미쳤을 수 있음을 시사 한다. 의도적 의사소통행동 빈도는 상호작용 대상자나 상황에 따 라 달라질 수 있으므로 빈도 자체를 절대적으로 고려할 수는 없겠
으나 최소한 12 개월 정도에는 분당 1 회 정도, 18 개월 전후해서는 분 당 2 회 정도의 의도적 의사소통행동을 기대해 볼수 있을 것이다.

의사소통기능은 각 범주별 사용 빈도와 유형 수 모두 연령에 따 른 유의한 차이를 나타냈다. 먼저 범주별 사용 빈도에서는 행동통 제적 기능 범주에서는 연령 집단 간에 유의한 차이가 없었던 반면, 사회적 상호작용과 동시주의 기능 범주에서는 연령 집단 간에 유의 한 차이를 보였다. 행동통제적 기능의 경우 12-18개월에는 가장 높 은 빈도를 보였으며 이후 연령 집단에서 사용 빈도에서 유의한 변화 가 없었다. 반면, 사회적 상호작용적 기능은 19-24개월까지는 변화 가 없다가 25-30개월에 유의하게 행동 빈도가 증가하였으며, 동시 주의적 기능은 19-24개월, 25-30개월로 점진적으로 사용 빈도가 증 가하여 25-30개월에 이르렀을 때에는 다른 두 범주의 의사소통기 능에 비하여 더 높은 사용 빈도를 보였다. 영유아들이 초기에는 주 로 사물이나 행동을 요구하거나 거부하는 것과 같은 행동통제적인 기능을 먼저 발달시키며, 다른 사람의 관심을 자신이나 제 3 의 대상 으로 유도하는 사회적 상호작용적 기능이나 동시주의적 기능은 상 대적으로 약간 늦게 발달한다는 점은 영어권 영유아들을 대상으 로 한 선행연구들을 통해서도 보고되었다(Chapman, 2000; Snow et al., 1996; Wetherby et al., 1988). Chapman (2000)은 구체적으로 사물이나 행동 요구 또는 거부하기, 언급하기 등의 기능은 8-15개 월 경에 관찰되며, 질문하기나 질문에 대답하기 등의 기능은 $16-23$ 개월경에 관찰된다고 보고하였다. 본 연구와 다른 분석 기준을 사용 하였으나 우리나라 영유아를 대상으로 보고된 Hong과 Kim (2001) 의 연구 결과도 19 개월에는 의사소통 의도가 반응과 요구가 전체의 절반 이상을 차지하였으나 연령이 증가함에 따라 반응과 요구가 차 지하는 비율은 감소하는 반면 언급과 진술의 비율은 점차적으로 증가하였다고 대체로 유사한 결과를 보고하였다. 본 연구의 결과와 선행연구의 결과들을 종합할 때, 대체로 12-18개월에는 요구하기, 거부하기와 같은 행동통제적 기능을 주로 사용하나, 24 개월 전후 해서는 언급하기, 보여주기, 정보 요구하기 등과 같은 동시주의적 기 능의 사용이 더 많아지는 것으로 결론지을 수 있을 것이다.

의사소통기능의 유형 수 역시 연령에 따른 유의한 증가를 보였 다. 특히 의사소통기능 범주 중 행동통제적 기능 범주와 사회적 상 호작용 기능 범주에서는 하위 의사소통기능 유형 수에서 연령에 따른 변화가 없었던 반면 동시주의 범주에서는 25-30개월에 유의 한 증가를 보였다. 언어이전 단계(평균 12 개월), 한 낱말 단계(평균 16 개월), 낱말조합 단계(평균 24 개월)의 세 연령 단계별로 의도적 의사소통행동을 살펴본 Wetherby 등(1988)은 모든 단계에서 거의 모든 유형의 의사소통기능이 관찰되었으며, 단지 주되게 사용하는 기능의 빈도에서만 차이가 있었다고 보고하였다. Hong과 Kim 
YoonKyoung Lee, et al. • Development of Intentional Communicative Behavior in Toddlers 12 to 30 Months COMmunication SCIINCES\& DIIORDERS

(2001)도 24개월경에는 연구자가 분석 39개의 의사소통기능 중 몇 개를 제외하고는 거의 모든 의사소통기능 유형을 나타냈다고 보고 했다. 본 연구에서도 12-18개월과 19-24개월 연령 집단 간에는 의 사소통기능 유형 수에 유의한 차이가 없는 것으로 나타나 선행연 구와 유사한 결과를 보였다. 그러나 24-30개월에는 동시주의 기능 범주의 유형 수에서는 유의한 증가를 보여 동시주의 기능은 사용 빈도만이 아니라 하위기능의 유형 수도 초기 의도적 의사소통행동 을 보여주는 민감한 지표가 될 수 있음을 시사하였다.

의사소통기능과 더불어 초기 의도적 의사소통행동 발달의 주요 지표가 되는 의사소통수단에서는 몸짓, 언어, 몸짓 동반 언어에서 만 연령에 따른 유의한 차이를 보였다. 영유아들은 19-24개월경에 몸짓은 감소한 반면, 언어와 몸짓 동반 언어는 증가하여 19 개월을 전후하여 주된 의사소통수단에 변화가 있었다. 일반적으로 12 개월 을 전후하여 첫 낱말을 사용하면서 언어 발달이 시작되는데, 언어 가 주된 의사소통수단이 되는 것은 19 개월 이후의 시기로 보는 것 이 적합하다. 이 역시 말이나 언어가 주된 의사소통 수단이 되는 것 은 18-24개월 정도가 되어야 가능해진다고 보고한 선행연구(Chapman, 2000; Ninio \& Snow, 1996; Paul, 2007; Wetherby et al., 1988) 들과 일치하는 것이라 할 수 있다. 본 연구에서는 19-24개월부터 언 어를 주된 의사소통수단으로 사용하기 시작하였으나 19-24개월에 는 몸짓 동반 언어를 언어에 비해 유의하게 많이 사용한 반면, 24-30 개월에는 언어와 몸짓 동반 언어가 거의 비슷하게 사용되었다. 이 러한 결과는 영유아들이 언어를 주된 수단으로 사용하기 전에 몸 짓을 동반하여 사용하는 시기를 거친다는 사실을 보여준다. 영유 아들이 언어습득 과정에서 부족한 언어를 몸짓으로 대체하며, 이 러한 몸짓 사용이 언어습득을 촉진하는 매개가 될 수 있음은 여러 연구를 통해 보고된 바 있다(Capirci, Iverson, Pizzuto, \& Volterra, 1996; Goodwyn \& Acredolo, 1993; Lee \& Lee, 2015; Thal \& Tobias, 1992). 본 연구 결과는 이러한 부분을 지지해주는 것이라 할수 있다. 마지막으로 앞에서 살펴본 초기 의도적 의사소통행동 변수들 중에서 생활연령 및 언어발달연령을 가장 잘 설명해 주는 것은 무 엇인지를 살펴본 결과, 생활연령 및 언어연령 모두 분당 의도적 의 사소통행동 빈도, 의사소통기능 중 동시주의적 기능과 사회적 상 호작용 기능, 의사소통수단 중에는 언어, 몸짓 동반 언어, 몸짓이 유의한 상관을 보였다. 이중 분당 의도적 의사소통행동 빈도는 생 활연령을 $41.9 \%$ 표현언어연령을 $40.6 \%$ 유의하게 설명하였다. 의사 소통기능 중에서는 동시주의 기능이 생활연령과 표현언어연령을 각각 $37.3 \%, 43.6 \%$ 설명해 주었으며, 의사소통수단에서는 몸짓 동 반 언어가 생활연령을 $51.1 \%$, 표현언어연령을 $51 \%$ 설명해 주는 것 으로 나타났다. 이러한 결과는 연령에 따른 결과에서 나타난 것과
마찬가지로 의도적 의사소통행동 빈도와 의사소통기능 중 동시주 의 기능, 그리고 몸짓 동반 언어가 영유아 시기의 연령에 따른 의사 소통 발달과 언어 발달을 가장 잘 설명해 주는 요인임을 확인해주 며, 나아가 영유아 시기의 의사소통 발달 평가 시 중요하게 고려해 야 하는 요인임을 시사한다.

본 연구는 12-30개월 사이의 영유아들을 대상으로 연령에 따른 초기 의도적 의사소통행동 발달 경향을 제시하였다는 점에서 의의 가 있다. 특히 구조화된 유도절차가 아니라 자연스러운 놀이 상황 에서 양육자와의 상호작용 상황에서 얻어진 자료를 분석한 결과이 기 때문에 영유아들의 일반적인 행동과 쉽게 비교할 수 있을 것이 다. 따라서 초기 의사소통 발달을 이해하는 데에는 물론, 영유아 시 기의 언어 또는 의사소통 발달이 지연된 영유아를 판별하거나 중 재를 계획할 때 기초 자료로 활용할 수 있다는 점에서 의의가 있을 것이다. 그러나 각 연령 집단별 사례수가 13 또는 14 명으로 많지 않 으며, 1 회 관찰을 통해 얻어진 자료만을 분석하였다는 점에서 제한 점이 있을 것이다. 이러한 점이 보완된 후속 연구를 기대한다.

\section{REFERENCES}

Bates, E., Camaioni, L., \& Volterra, V. (1975). The acquisition of performatives prior to speech. Merrill-Palmer Quarterly of Behavior and Development, $21,205-226$

Bayley, N. (1993). Bayley scales of infant development: manual. New York, NY: Psychological Corporation.

Bornstein, M. H., Tamis-LeMonda, C. S., Tal, J., Ludemann, P., Toda, S., Rahn, C. W., ... \& Vardi, D. (1992). Maternal responsiveness to infants in three societies: the United States, France, and Japan. Child Development, 63, 808821.

Brady, N. C., Marquis, J., Fleming, K., \& McLean, L. (2004). Prelinguistic predictors of language growth in children with developmental disabilities. Journal of Speech, Language, and Hearing Research, 47, 663-677.

Bruner, J. (1981). The social context of language acquisition. Language \& Communication, 1, 155-178.

Calandrella, A. M., \& Wilcox, M. J. (2000). Predicting language outcomes for young prelinguistic children with developmental delay. Journal of Speech, Language, and Hearing Research, 43, 1061-1071.

Capirci, O., Iverson, J. M., Pizzuto, E., \& Volterra, V. (1996). Gestures and words during the transition to two-word speech. Journal of Child Language, 23, 645-673.

Chapman, R. S. (2000). Children's language learning: an interactionist per- 
spective. Journal of Child Psychology and Psychiatry, 41, 33-54.

Chiat, S., \& Roy, P. (2008). Early phonological and sociocognitive skills as predictors of later language and social communication outcomes. Journal of Child Psychology and Psychiatry, 49, 635-645.

Cho, B. H., \& Park, H. W. (2006). Korean-Bayley Scales of Infant Development II (K-BSID-II). Seoul: Mindpress.

Cho, M. R., \& Lee, Y. K. (2010). Communicative behaviors of toddlers with or without language delay. Korean Journal of Early Childhood Special Education, 10, 31-46.

Choi, Y. J., \& Lee, Y. K. (2011). The relationship between symbolic play development and early vocabulary acquisition in toddlers. Korean Journal of Communication Disorders, 16, 248-260.

Dore, J. (1975). Holophrases, speech acts and language universals. Journal of Child Language, 2, 21-40.

Goodwyn, S. W., \& Acredolo, L. P. (1993). Symbolic gesture versus word: is there a modality advantage for onset of symbol use? Child Development, 64, 688-701.

Halliday, M. A. K. (1975). Learning how to mean: explorations in the development of language. London: Edward Arnold.

Hong, G. H., \& Kim, Y. T. (2001). A longitudinal study of the acquisition of communicative intentions. Korean Journal of Communication Disorders, 6 , $1-21$.

Jeon, J., Lee, H., \& Lee, Y. (2013). Comparison of language and social communication abilities of toddlers who are at risk of autism spectrum disorders and developmental language delay. Communication Sciences \& Disorders, $18,349-359$.

Jung, K. H., \& Pae, S. (2006). The early semantic and gestural development of Korean children. Korean Journal of Communication Disorders, 11, 1-13.

Kim, J. M., \& Mahoney, G. (2004). The effects of mother's style of interaction on children's engagement implications for using responsive interventions with parents. Topics in Early Childhood Special Education, 24, 31-38.

Kim, J. W., Choi, J., \& Lee, Y. (2015). Communicative acts of toddler with ASD in emerging language stage. Korean Journal of Early Childhood Special Education, 15, 51-67.

Kim, K. S. (2004). Korean toddlers' development of communication functions (Master's thesis). Hallym University, Chuncheon, Korea.

Kim, R. Y., Lee, H. J., \& Lee, Y. K. (2015). The effect of book reading and play situations on the communicative acts of late-talking toddlers and their mothers. Journal of Speech-Language \& Hearing Disorders, 24, 15-27.

Kim, Y. S., \& Kwak, K. J. (2010). The relationship between maternal verbal responsiveness, infant's social communication ability during infancy and language ability in early childhood. Korean Journal of the Human Development, 17, 191-207.

Kim, Y. T., Kim, K. H., Yoon, H. R., \& Kim, H. S. (2003). Sequenced Language Scale for Infants (SELSI). Seoul: Special Education Publishing.

Kwak, K. J., Kim, M. H., \& Chang-Song, Y. K. (2004). Early development of intentional communicative abilities in Korean infants. Korean Journal of the Human Development, 11, 49-69.

Lee, Y. K., \& Seol, A. (2012). Maternal communication style of toddlers with developmental language delay during toddler-mother interaction. Korean Journal of Communication Disorders, 17, 263-273.

Lee, H. J., \& Lee, Y. (2014). Characteristics of social communication behavior in preterm toddlers. Korean Journal of Early Childhood Special Education, $14,105-120$.

Lee, Y., \& Lee, H. (2013). Conversational turn-taking of toddlers with language delay. Special Education Research, 12, 357-377.

Lee, Y., \& Lee, H. (2015). Communicative Gestures in toddlers with developmental language delay and their relations to language development. Communication Sciences \& Disorders, 20, 255-265.

Lim, H., Pae, S., \& Song, S. (2001). A study of communicative characteristics of Korean children at one-word stage: comparison between language delayed children and normal children in facilitative play contexts. Korean Journal of Communication Disorders, 6, 313-330.

Ninio, A., \& Snow, C. E. (1996). Pragmatic development. Boulder, CO: Westview Press.

Owens, R. E. (2015). Language development: an introduction (9th ed.). Harlow, UK: Pearson.

Paul, R. (2007). Language disorders from infancy through adolescence: assessment \& intervention (3rd ed.). St. Louise, MO: Mosby/Elsevier.

Paul, R., \& Roth, F. P. (2011). Characterizing and predicting outcomes of communication delays in infants and toddlers: implications for clinical practice. Language, Speech, and Hearing Services in Schools, 42, 331-340.

Paul, R., \& Shiffer, M. E. (1991). Communicative initiations in normal and late-talking toddlers. Applied Psycholinguistics, 12, 419-431.

Rescorla, L., \& Fechnay, T. (1996). Mother child synchrony and communicative reciprocity in late-talking toddlers. Journal of Speech, Language, and Hearing Research, 39, 200-208.

Snow, C. E., Pan, B. A., Imbens-Bailey, A., \& Herman, J. (1996). Learning how to say what one means: a longitudinal study of children's speech act use. Social Development, 5, 56-84. 
YoonKyoung Lee, et al. • Development of Intentional Communicative Behavior in Toddlers 12 to 30 Months CCMMUNICATION SCIENCES\& DISORDERS

Thal, D. J., \& Tobias, S. (1992). Communicative gestures in children with delayed onset of oral expressive vocabulary. Journal of Speech, Language, and Hearing Research, 35, 1281-1289.

Watt, N., Wetherby, A., \& Shumway, S. (2006). Prelinguistic predictors of language outcome at 3 years of age. Journal of Speech, Language, and Hearing Research, 49, 1224-1237.

Wetherby, A. M., \& Prizant, B. M. (2002). CSBS manual: communication and symbolic behavior scales. Baltimore, MD: Paul H. Brookes Publishing.
Wetherby, A. M., Cain, D. H., Yonclas, D. G., \& Walker, V. G. (1988). Analysis of intentional communication of normal children from the prelinguistic to the multiword stage. Journal of Speech, Language, and Hearing Research, $31,240-252$.

Yoder, P. J., Warren, S. F., \& McCathren, R. B. (1998). Determining spoken language prognosis in children with developmental disabilities. American Journal of Speech-Language Pathology, 7, 77-87. 
Appendix 1. 의도적 의사소통행동 분석 기준

\begin{tabular}{|c|c|c|}
\hline 유형 & 정의 및 하위 유형 & 예 \\
\hline \multicolumn{3}{|c|}{ 의도적 의사소통행동 의도를 담은 행동으로 다든 } \\
\hline \multicolumn{3}{|l|}{ 의사소통 기능 } \\
\hline 행동통제 & $\begin{array}{l}\text { 특정한 결과를 얻기 위해 상대방의 행동을 통제하는 것과 관련된 기능. } \\
\text { 사물 및 행동 요구하기, 사물 및 행동 거부하기가 포함됨 }\end{array}$ & 엄마가 들고 있는 포크를 향해 손을 뻗음 \\
\hline 사회적 상호작용 & $\begin{array}{l}\text { 상대방의 주의를 자기에게 유도하거나 유지하기 위한 기능. 인사하기, } \\
\text { 부르기, 보여주기가 포함됨 }\end{array}$ & 자기를 바라보게 하려는 의도로 엄마를 향해 소리를 지름 \\
\hline 동시주의 & $\begin{array}{l}\text { 상대방의 주의를 제3의 사건 혹은 사물로 유도하거나 유지하기 위한 기능. } \\
\text { 언급하기와 질문하기가 포함됨 }\end{array}$ & $\begin{array}{l}\text { 바닥에 우유가 쏟아지자 손가락으로 우유를 가리키면서 엄마를 바 } \\
\text { 라봄 }\end{array}$ \\
\hline \multicolumn{3}{|l|}{ 의사소통 수단 } \\
\hline 몸짓 & $\begin{array}{l}\text { 의도를 전달하기 위해 손이나 머리 등을 사용한 몸짓. 가리키기, 주기, 보여주 } \\
\text { 기, 손 내밀기, 손 흔들기, 손 가로젓기, 고개 가로젓기, 끄덕이기가 포함됨 }\end{array}$ & 엄마가 들고 있는 포크를 요구하는 의미로 손을 내밈 \\
\hline 발성 & $\begin{array}{l}\text { 의도를 전달하기 위해 산출한 전사 가능한 모음 및 자음. 의미 해석이 어려운 } \\
\text { 모음 위주 발성, 모음 유사소리, 자음 포함 음절 및 의성어가 포함됨 }\end{array}$ & 엄마의 주의를 끌기 위해 “어어”발성 \\
\hline 몸짓 동반 발성 & 의도를 전달하기 위해 앞에서 정의한 몸짓과 발성을 동시에 사용한 경우 & 과자를 달라고 손을 내밀며 “어어”라고 소리를 냄 \\
\hline 언어 & 의미 해석이 가능한 발화로, 낱말과 문장 산출 등이 포함됨 & "맘마"라고 말하여 먹을 것을 요구함 \\
\hline 몸짓 동반 언어 & 의도를 전달하기 위해 몸짓과 언어를 동시에 사용한 경우를 말함 & 우유병을 손가락으로 가리키면서 “우유”라고 말하여 달라고 요구함 \\
\hline
\end{tabular}


YoonKyoung Lee, et al. • Development of Intentional Communicative Behavior in Toddlers 12 to 30 Months

\section{국문초록}

\section{2-30개월 영유아의 의도적 의사소통 행동 발달}

이윤경 $\cdot$ 이효주 ${ }^{2}$

1한림대학교 언어청각학부, ${ }^{2}$ 한림대학교 대학원 언어병리청각학과

배경 및 목적: 영유아 시기의 의도적 의사소통행동 발달은 의사소통 발달의 기초가 되며, 추후 언어 발달과도 밀접한 관계를 갖는다. 본 연구는 12-30개월 사이의 영아들을 대상으로 의도적 의사소통행동 발달을 살펴보는 것을 목적으로 하였다방법: 12-30개월 사이의 전형적 발달 영유아 41 명을 대상으로 하였다. 참여 영유아는 6 개월 간격의 세 연령 집단으로 구분하였으며, 각각 참가자는 12-18개월 13 명, 19-24개월 14명, 25-30개월 14명이었다. 의도적 의사소통행동은 영유아와 양육자 간의 놀이 상황에서 수집된 10 분간의 상호작용 행 동표본을 분석하였으며, 분당 의도적 의사소통행동 빈도, 의도적 의사소통행동의 기능(행동통제적, 사회적 상호작용적, 동시주의적), 의도적 의사소통행동의 수단(몸짓, 발성, 몸짓 동반 발성, 언어, 몸짓 동반 언어)을 측정하였다. 측정된 결과는 일원분산분석과 이원분 산분석, 단순 및 중다회귀분석으로 통계 분석하였다. 결과: 분당 의도적 의사소통행동 빈도는 연령에 따라 유의하게 증가하였다. 의사 소통기능 범주별 사용 빈도는 동시주의와 사회적 상호작용 기능 범주에서 연령에 따라 유의한 증가를 보였으며, 기능 범주별 하위기능 유형 수는 동시주의에서만 연령에 따른 유의한 차이를 보였다. 의사소통수단에서는 몸짓은 연령 증가에 따라 유의하게 감소한 반면, 몸 짓 동반 언어와 언어의 사용은 연령에 따라 유의하게 증가하였다. 분당 의도적 의사소통행동 빈도와 동시주의 기능, 몸짓 동반 언어가 생활연령 및 언어발달연령을 유의하게 설명하는 것으로 나타났다. 논의 및 결론: 본 연구의 결과는 12-30개월 한국 영유아의 초기 의 도적 의사소통행동 발달을 보여주며, 영유아 시기의 의도적 의사소통 발달 평가 및 중재에 활용할 수 있을 것이다.

핵심어: 영유아, 의도적 의사소통행동, 의사소통기능, 의사소통수단

본 연구는 2016학년도 한림대학교 교내 학술연구비(HRF-201516-012)의 지원을 받아 수행되었음.

\section{참고문헌}

곽금주, 김민화, 장유경(2004). 한국영아들의 초기 비언어적 의사소통에서 보이는 의도성 발달. 인간발달연구, 11, 49-69.

김기숙(2004). 12개월, 18개월, 24개월 유아의 의사소통 횟수와 의사소통 기능발달. 한림대학교대학원 석사학위논문.

김란영, 이효주, 이윤경(2015). 책 읽기와 놀이 조건이 말 늦은 영유아와 어머니의 의사소통 행동에 미치는 영향. 언어치료연구, 24, 15-27.

김연수, 곽금주(2010). 영아기 어머니의 언어적 반응성 및 영아의 비언어적 의사소통능력과 아동 초기 언어능력 간의 관계. 인간발달연구, 17, 191-207.

김영태, 김경희, 윤혜련, 김화수(2003). 영유아 언어발달 검사(SELSI). 서울: 도서출판 특수교육.

김지원, 최지은, 이윤경(2015). 초기언어발달단계 자폐스펙트럼장애 유아의 의도적 의사소통 행동 특성. 유아특수교육연구, 15, 51-67.

이윤경, 설아영(2012). 영유아-어머니 상호작용에서의 언어발달지체 영유아 어머니 의사소통 행동 특성. 언어청각장애연구, 17, 263-273.

이윤경, 이효주(2013). 표현언어발달지체 영유아의 대화차례 주고받기 특성. 특수교육, 12, 357-377.

이윤경, 이효주(2015). 언어발달지체 영아의 의사소통적 제스처 특성과 언어발달과의 관계. 언어청각장애연구, 20, 255-265.

이효주, 이윤경(2014). 미숙아출생 영유아의 사회적 의사소통 행동 특성. 유아특수교육연구, 14, 105-120.

임현숙, 배소영, 송승하(2001). 한낱말 단계 아동의 의사소통 특성 연구: 아동특성과 놀이 조건을 고려하여. 언어청각장애연구, 6, 313-330.

전진아, 이효주, 이윤경(2013). 자폐범주성장애 의심 영유아와 언어발달지체 영유아의 언어및 사회적 의사소통 능력 비교. 언어청각장애연구, 18 ,

349-359.

정경희, 배소영(2006). 한국 영유아의 제스츄어 및 의미 발달. 언어청각장애연구, 11, 1-13.

조미라, 이윤경(2010). 언어발달지체 유아와 일반 유아의 의사소통 행동 비교. 유아특수교육연구, 10, 31-46.

조복희, 박혜원(2006). 한국-베일리 영유아발달검사(K-BSID-II). 서울: 마인드프레스.

최윤지, 이윤경(2011). 영유아의 상징놀이 발달과 초기 표현 어휘 발달과의 관계. 언어청각장애연구, 16, 248-260.

홍경훈, 김영태(2001). 아동의 의사소통의도 습득에 대한 종단연구. 언어청각장애연구, 6, 1-21. 